\title{
Arbor
}

\section{Biotecnología y medicamentos}

\author{
José Antonio Melero Fondevila
}

Arbor CLXXIX, 705 (Septiembre 2004), 141-158 pp.

Sin entrar en disquisiciones sobre la definición de la Biotecnología, me referiré a esta como el conjunto de técnicas y tecnologías desarrolladas en los últimos 30 años para el estudio y manipulación del material genético de los seres vivos. Aunque el propio nombre tiene un sentido de aplicación tecnológica, no es menos cierto que la Biotecnología ha tenido un extraordinario impacto en ampliar nuestro conocimiento de la Biología. Sin embargo, me referiré en este capítulo sólo a los aspectos más aplicados de la Biotecnología en el campo biosanitario, como valor añadido de la Ciencia en beneficio de la humanidad.

Para una mejor comprensión de la Biotecnología, presentaré sus diversos aspectos en apartados distintos cuyos límites he definido arbitrariamente:

1. Ingeniería genética: Las técnicas para la manipulación del material genético en el tubo de ensayo empezaron a desarrollarse a principios de los años 1970. Herbert Boyer y Stanley Cohen (1), en la Universidad de Stanford (California, USA), fueron los primeros en utilizar plásmidos bacterianos para su manipulación «in vitro». Estas pequeñas moléculas circulares de DNA se encuentran en bacterias como formas extracromosómicas que confieren resistencia a determinados antibióticos. Su pequeño tamaño fue una ventaja para que Boyer y Cohen aislaran dos plásmidos distintos, los cortaran en fragmentos más pequeños utilizando enzimas de restricción (ver glosario) y reconstruyeran un nuevo plásmido a partir de fragmentos de cada uno de los originales. Esta nueva molécula de DNA, cuando se reintroducía en una bacteria, confería resistencia frente a los dos antibióticos para los que eran resistentes las bacterias portadoras de los plásmidos originales. Esto, a su vez, permitía aislar de nuevo el plásmido generado en el tubo de ensayo para su caracterización y/o posterior manipulación. 
Los resultados de Boyer y Cohen se extendieron rápidamente a la manipulación de otras moléculas sencillas de DNA, principalmente genomas de virus animales y bacterianos, creando nuevas moléculas quimé ricas de DNA que nunca habían existido $(2,3)$. La revolución que se dio en llamar tecnología del DNA recombinante y, posteriormente, Ingeniería Genética había comenzado. En 1975 tuvo lugar la conferencia de Asilomar, en la que más de un centenar de destacados biólogos moleculares se reunieron para evaluar los riesgos de la manipulación «in vitro» de DNA. Su principal preocupación era las consecuencias que esta tecnología podría tener para la salud pública y el medioambiente. Muchas de las preguntas que entonces se planteaban han quedado resueltas a lo largo de los últimos 25 años pero quedan otras que aún hoy son tema de debate en los ámbitos de la propiedad intelectual (por ejemplo, posibilidad de patentar genes) o de la ética (por ejemplo, manipulación y clonación de embriones humanos). De forma análoga a los planteamientos que se hicieron en los años 1940 y 1950 en el ámbito de la Física Nuclear, la Ingeniería Genética se debate actualmente en distintos foros donde se sopesan los beneficios que puede aportar a la humanidad junto con los riesgos que acarrea el mal uso de la misma.

Una cosa debe quedar clara, sin embargo, y es que, en la mayoría de los casos, los organismos manipulados genéticamente son menos peligrosos que otros muchos creados por la evolución natural a lo largo de millones de años. Parafraseando a Sydney Brenner, la Ingeniería Genética todavía está en su etapa infantil de «prueba y error». Al contrario de lo que sucede con la Ingeniería convencional -en la que un cálculo de resistencias de materiales puede predecir las propiedades del puente que se desea construir- las propiedades de los organismos manipulados genéticamente son casi siempre impredecibles y deben evaluarse a posteriori. Cabe insistir, sin embargo, que en la mayoría de los casos el resultado es un organismo más débil y peor adaptado que el organismo de partida.

El procedimiento utilizado por Boyer y Cohen para la manipulación de plásmidos bacterianos sigue siendo la base de la Ingeniería Genética actual (Figura 1). En general, una molécula de DNA denominada vector (casi siempre un plásmido) se utiliza para incorporar un fragmento de otro DNA y amplificarlo millones de veces. Hoy en día se han diseñado estrategias para introducir este nuevo DNA en células de plantas, animales o humanas en cultivo para modificarlas genéticamente. Así mismo, es posible manipular células en cultivo para su implantación en embriones que dan lugar a animales genéticamente manipulados. La «fabricación» de células u organismos en los que se ha eliminado o incor- 


\section{Biotecnología y medicamentos}

porado un nuevo gen, o genes, permite explorar rápidamente las consecuencias de esas alteraciones $\mathrm{y}$, por consiguiente, aventurar la posible función de los correspondientes productos génicos ó proteínas. La tarea clásica del bioquímico para esclarecer la función que realiza una determinada proteína se ha visto sobrepasada, en gran medida, por la del ingeniero genético.

FiguRA 1. Esquema de clonaje de DNA en un Plásmido bacteriano

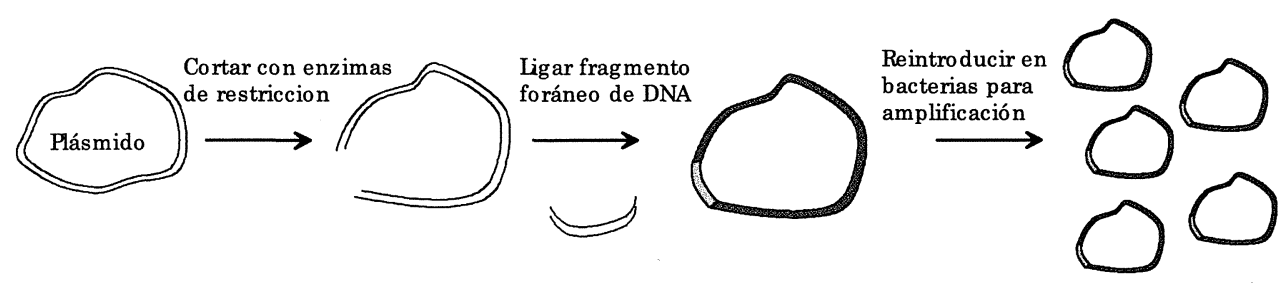

Un plásmido aislado de una bacteria determinada y que confiere resistencia a algún antibiótico es cortado por la acción de enzimas de restricción. El DNA cortado se liga a un fragmento exógeno de DNA por la acción de un enzima, denominado DNA ligasa. El nuevo DNA se introduce en bacterias, para su amplificación, reaislamiento y caracterización.

Las técnicas de la Ingeniería Genética han permitido un avance espectacular en el conocimiento de procesos biológicos, tales como la diferenciación celular y la embriogénesis, así como en el conocimiento de enfermedades tan complejas como el cáncer. Así mismo, la Ingeniería Genética ha permitido crear genes nuevos que codifican para proteínas con propiedades que nunca se habrían podido conseguir por los métodos de la genética clásica, lo que representa un salto cualitativo para el desarrollo de nuevos fármacos. Aunque todos estos trabajos tienen una actualidad indudable y quedan muchas preguntas por contestar, el camino recorrido durante los últimos años ha sido realmente espectacular.

Dejando de lado, por tanto, los avances conseguidos en la ciencia básica, me referiré a continuación a las aplicaciones que la Ingeniería Genética ha tenido en los últimos años en el campo biosanitario y su desarrollo potencial a corto y medio plazo.

1.1. Vacunas: Entre las primeras aplicaciones que se vaticinaron para la Ingeniería Genética estaba el desarrollo de nuevas vacunas o la mejora de las ya existentes. Así resultó ser en el caso de la vacuna frente al virus de la hepatitis B (VHB). Esta vacuna, empezada a utilizarse en los años 80 , se producía originalmente a partir de plasma sanguíneo de individuos portadores del virus. En el hígado de estos individuos se produ- 
ce una gran cantidad del antígeno de superficie de la partícula viral que se libera a la sangre, a partir de la cual se puede purificar dicho antígeno. El antígeno purificado se utilizaba como vacuna para inmunizar a individuos sanos frente a la infección por el virus. Sin embargo, esa vacuna tenía el riesgo potencial de que las preparaciones de antígeno llevasen trazas de virus infectivo que podían ocasionar el desarrollo de una hepatitis en el individuo receptor de la vacuna. La introducción del gen que codifica para el antígeno de superficie del VHB en células de hámster en cultivo, permitió la obtención de clones celulares que producían dicho antígeno y lo excretaban al medio de cultivo, de donde se pudo purificar para la preparación de una nueva vacuna, sin el riesgo de que pudiese ir acompañada de virus infectivo.

Aunque hoy en día la vacuna frente al VHB sigue siendo la única que se ha desarrollado empleando exclusivamente técnicas de ingeniería genética, hay en curso la obtención de un buen número de vacunas empleando diversas aproximaciones que se resumen en la Tabla I.

TABLA I. Ejemplos de vacunas obtenidas mediante técnicas de ingeniería genética o en proceso de desarrollo

\begin{tabular}{lll} 
Tipo de vacuna & $\begin{array}{l}\text { Sistema de } \\
\text { producción }\end{array}$ & Ejemplo \\
\hline Antígeno purificado & Células en cultivo & Virus de la hepatitis B \\
Virus atenuados & Células en cultivo & Virus de la gripe \\
$\begin{array}{l}\text { Microorganismos } \\
\text { modificados }\end{array}$ & $\begin{array}{l}\text { Cultivos } \\
\text { bacterianos }\end{array}$ & Tuberculosis \\
DNA/RNA & $\begin{array}{l}\text { Cultivos } \\
\text { bacterianos }\end{array}$ & $\begin{array}{l}\text { Virus de la inmunodeficiencia } \\
\text { humana }\end{array}$
\end{tabular}

Aparte de la producción de antígenos, ya expuesta para el caso de la vacuna frente el VHB, la manipulación genética de diversos virus permite su atenuación para usarse como vacunas. Los virus atenuados son capaces de producir una infección limitada en el individuo, sin causar enfermedad, pero suficiente para estimular una respuesta inmune protectora frente al patógeno virulento. La «lógica» de esta aproximación es la misma que utilizó Albert Sabin para producir en los años 1950 la vacuna frente a la poliomielitis y que ha permitido la casi total erradicación de este virus de la faz de la Tierra. Pero mientras Sabin tuvo que 
utilizar un método totalmente empírico -basado en la infección repetida de animales de laboratorio con el virus de la polio, hasta seleccionar alguno que estuviese atenuado- la manipulación genética de los virus nos permite la obtención rápida de una variedad de virus de "diseño» que tengan las propiedades deseadas de atenuación. Así, la manipulación genética del virus de la gripe ha permitido el desarrollo de virus atenuados que parecen tener una mayor eficacia como vacunas que las actualmente utilizadas, basadas en virus inactivados químicamente o en antígenos semipurificados.

La manipulación de los genomas víricos permite también generar virus que sean portadores de antígenos útiles para la vacunación frente a infecciones, o enfermedades, no relacionadas con el virus en cuestión. Valga como ejemplo la manipulación del genoma del virus vaccinia, utilizado ampliamente en las campañas de vacunación que resultaron en la erradicación de la viruela. Hoy en día, se están generando virus vaccinia portadores de antígenos relevantes para la inmunización frente al virus de la inmunodeficiencia humana -causante del SIDA-o del parásito productor de la malaria (4).

Pero las aplicaciones de virus manipulados genéticamente no se restringen al desarrollo de vacunas para prevenir enfermedades infecciosas. Actualmente hay una gran actividad para manipular virus dirigidos frente a determinados tumores, con el fin de utilizarlos terapéuticamente. Así un virus común como el adenovirus se ha manipulado para que infecte solamente células en las que el gen supresor de tumores p53 esté inactivo, lo que es una situación frecuente en tumores de distinto tipo. En combinación con otras drogas, la administración local del «adenovirus recombinante» ha tenido resultados prometedores en las fases I y II de ensayos clínicos llevados a cabo en pacientes con tumores de cabeza y cuello, con una remisión total de este tipo de cáncer en un $27 \%$ de los enfermos. Actualmente, el adenovirus recombinante está en la fase III de ensayos clínicos para una mejor evaluación de su potencial terapéutico.

De la misma manera que se pueden manipular los genomas víricos, también se puede manipular el genoma de otros microorganismos para utilizarse como vacunas frente a las enfermedades que ellos mismos causan o para que sean portadores de antígenos foráneos. Así, la cepa vacunal de la bacteria causante de la tuberculosis, que se ha utilizado de manera extensiva en algunos países, se está manipulando para utilizarse como vacuna frente a otros patógenos humanos. Del mismo modo, una cepa de $V$. Cholera se ha manipulado genéticamente para su atenuación y uso como vacuna frente al cólera (Tabla II). 
TABLA II. Ejemplos de productos biotecnológicos aprobados recientemente por la Agencia Europea del Medicamento para su uso en humanos

\begin{tabular}{|c|c|c|}
\hline Producto & Principio activo & Aplicación \\
\hline Avonex & Interferón beta-1a & Esclerosis múltiple \\
\hline Betaferón & Interferón beta- $1 b$ & Esclerosis múltiple \\
\hline Orochol & $\begin{array}{l}V . \text { Cholerae genéticamente } \\
\text { modificado }\end{array}$ & Vacunación frente al cólera \\
\hline Enbrel & $\begin{array}{l}\text { Proteína quimérica del receptor } \\
\text { del factor necrosante tumoral y del } \\
\text { fragmento Fc de inmunoglobulinas }\end{array}$ & Artritis reumatoide \\
\hline Xolair & $\begin{array}{l}\text { Anticuerpo monoclonal humanizado } \\
\text { anti-IgE }\end{array}$ & Rinitis alérgica y asma \\
\hline Pegasys & $\begin{array}{l}\text { Interferón alfa, modificado con } \\
\text { polietilenglicol }\end{array}$ & Hepatitis C \\
\hline Somavert & $\begin{array}{l}\text { Antagonista de la hormona de crecimiento } \\
\text { modificado con polietilenglicol }\end{array}$ & Acromegalia \\
\hline Remicade & $\begin{array}{l}\text { Anticuerpo monoclonal anti-factor } \\
\text { necrosante tumoral }\end{array}$ & Artritis reumatoide \\
\hline Synagis & $\begin{array}{l}\text { Anticuerpo monoclonal humanizado } \\
\text { anti-proteina F del virus respiratorio } \\
\text { sincitial }\end{array}$ & $\begin{array}{l}\text { Prevención de infecciones } \\
\text { por el virus respiratorio } \\
\text { sincitial }\end{array}$ \\
\hline
\end{tabular}

Quizá el desarrollo más espectacular en el campo de las vacunas, por simple e inesperado, haya sido el uso de ácidos nucleicos como agentes vacunales en lugar de los que se empleaban tradicionalmente (antígenos proteicos purificados o microorganismos atenuados o inactivados). Como suele suceder en la investigación científica, un resultado fortuito permitió observar a Margaret Liu y col. (5) que cuando un plásmido portador de la nucleoproteína del virus de la gripe se inoculaba intramuscularmente a ratones se inducía una respuesta inmune protectora frente a dicho virus. Al parecer, las moléculas de DNA inyectadas eran captadas por las células del organismo que, entonces, iniciaban la producción de la nucleoproteína y, consecuentemente, se disparaba la respuesta del sistema inmune frente a este antígeno viral. Este nueva forma de inmuniza- 


\section{Biotecnología y medicamentos}

ción (o vacunación) se ha extendido a un gran número de antígenos virales, bacterianos y de parásitos.

La inmunización con DNA ofrece una serie de ventajas frente a las vacunas tradicionales. En primer lugar cabe destacar la facilidad de la producción de estas vacunas, puesto que la preparación de grandes cantidades de DNA es un proceso fácil y barato. En segundo lugar, la gran estabilidad del DNA permite su fácil distribución para campañas masivas de vacunación, sobre todo en países en vías de desarrollo. A pesar de estas ventajas, las vacunas de DNA son todavía objeto de intensa experimentación en modelos animales para entender su modo de acción y, sobre todo, estudiar sus posibles aspectos adversos. Entre estos cabe destacar la posible incorporación del DNA foráneo en las células de organismo y su transformación en células cancerosas, así como la posible respuesta inmunopatológica frente a la producción continuada del antígeno extraño en el individuo receptor.

1.2. Agentes terapéuticos: Mientras que el arsenal de drogas para combatir las enfermedades tuvo su origen, en primer lugar, en productos de origen natural y, posteriormente, en productos obtenidos por síntesis química, la nueva fuente de agentes terapéuticos se ha basado en productos derivados de la Biotecnología. Estos nuevos productos se diferencian de los primeros no solo en su origen y forma de producción sino, principalmente, en la concepción de los mismos. Así, mientras que las drogas tradicionales se usaban farmacológicamente antes de que se conociese su modo de actuación (baste como ejemplo la aspirina cuyo mecanismo de acción se está desentrañando en los últimos años), los productos biotecnológicos se diseñan a partir de conocimientos, al menos parciales, de su actividad fisiológica.

De la misma manera que para el caso de las vacunas, los productos biotecnológicos con aplicaciones terapéuticas pueden sustituir a medicamentos ya existentes (para mejorar su seguridad o disponibilidad) o para diseñar nuevas drogas con aplicaciones desconocidas hasta el momento. Como ejemplo del primer tipo de productos cabe reseñar la insulina humana. Esta hormona, esencial para el tratamiento de la diabetes tipo I, se obtenía ante riormente de extractos pancreáticos porcinos o bovinos, de donde se purificaba mediante procesos complejos y costosos. Sin embargo, la insulina porcina o bovina, aunque parecida a la insulina humana, tiene ciertas diferencias en la secuencia de aminoácidos cuya influencia inmunopatoló gica es desconocida. El propio origen de la insulina de cerdo o de vaca condicionaba su seguridad al poder estar contaminada con virus u otros agentes patógenos que tuviesen efectos adversos sobre el paciente diabético. 
La insulina fue uno de los primeros medicamentos biotecnológicos que en los años 1980 reemplazaron a los que se utilizaban anteriormente. El gen de la insulina insertada en un plásmido bacteriano adecuado permitía la producción masiva de esta hormona en bacterias, sin limitaciones de su fuente de producción. La producción a gran escala de dicha hormona en fermentadores y su purificación posterior se veía también sustancialmente simplificada al partir de extractos bacterianos en los que la insulina representaba una parte importante de la proteína total de partida. De la misma manera se han ido reemplazando otras hormonas peptídicas, tales como la hormona del crecimiento, por productos homónimos obtenidos biotecnológicamente.

Algunos ejemplos de productos biotecnológicos que se han aprobado recientemente por la Agencia Europea del Medicamento para su uso farmacológico en humanos se muestran en la Tabla II. Algunos de estos productos tenían serias limitaciones para su producción industrial, puesto que se producen en cantidades muy pequeñas por ciertas células de nuestro organismo. Tal es el caso de citoquinas y quimioquinas, como los interferones $\alpha, \beta$ y $\gamma$. Estos se empezaron a producir industrialmente a partir de cultivos de leucocitos humanos, estimulados «in vitro " por ciertos virus. El resultado, sin embargo, era una mezcla de distintos tipos de interferón cuyo coste de producción era, además, enormemente alto. Hoy en día, se han clonado los genes que codifican distintos interferones y se han introducido en células en cultivo, lo que ha permitido abaratar los costes de producción y la obtención de productos bioquímicamente homogéneos para el tratamiento de diversas enfermedades infecciosas o autoinmunes.

Quizá las posibilidades terapéuticas de nuevos productos biotecnológicos estén en gran medida por desarrollar. Como se ha mencionado anteriormente, la "fabricación» de nuevos genes que incorporen, por ejemplo, fragmentos de genes distintos pueden dar lugar a proteínas con propiedades farmacológicas hasta ahora desconocidas. Este es el caso de moléculas como el Enbrel, que resultan de la fusión del receptor del factor necrosante tumoral ("tumor necrosis factor", TNF) y de la región Fc de las moléculas de inmunoglobulinas. Este nuevo producto se está utilizando actualmente en el tratamiento de la artritis reumatoide (Tabla II).

Mientras que la farmacología clásica se ha basado en la administración iatrogénica de agentes profilácticos o terapéuticos, la biotecnología permite la modificación de organismos productores de principios biológicos con propiedades farmacológicas y aumentar las posibilidades de su administración. Por ejemplo, la obtención de plantas «transgénicas» (por- 


\section{Biotecnología y medicamentos}

tadoras de un nuevo gen) productoras de determinados antígenos puede servir para la inmunización por vía alimentaría frente a determinados agentes infecciosos. De forma análoga, la obtención de animales «transgénicos (vacas u ovejas) puede servir para la producción de leche portadora de determinados agentes medicinales y su administración vía alimentaría o la purificación de esos agentes a partir de diversos fluidos biológicos (leche, sangre, orina, etc.).

1.3. Terapia génica y/o celular: Existe un gran número de enfermedades hereditarias en las que la deficiencia de un gen funcional conduce a patologías tan diversas como la fibrosis quística o la hemofilia. En estos casos, la terapia ideal es la reparación del gen defectuoso por otro que tenga las propiedades funcionales del gen normal ("terapia génica») o la administración de células portadoras del gen normal que mitiguen los efectos de su ausencia en las células del organismo ("terapia celular»). Aunque este tipo de terapias se han probado en un buen número de modelos animales, su aplicación en humanos todavía se encuentra en fase de experimentación clínica.

Son muchos los factores que han contribuido a la lenta introducción de la terapia génica para su utilización en humanos. El principal problema ha sido, quizá, la ausencia de un método que permita dirigir de forma eficiente y específica el gen, cuya anomalía se quiere corregir, a un determinado órgano o tejido. La mayoría de los métodos ideados para la introducción de genes en las células somáticas de un individuo se basan en el uso de vectores virales; es decir, virus no patógenos, modificados genéticamente, portadores del gen "corrector». Estos virus tienen, sin embargo, una especificidad celular o de tejido solamente parcial, por lo que pueden liberar dicho gen no solo en las células diana que se quiere modificar sino también en otros tipos celulares con consecuencias impredecibles para el paciente. $R e-$ cientes fallecimientos en pruebas clínicas de terapia génica, cuyas causas aún no están totalmente esclarecidas, han contribuido a aumentar las reservas sobre la seguridad de este tipo de tratamientos.

Las posibilidades de la terapia génica no están limitadas a las enfermedades consideradas clásicamente como hereditarias. El cáncer, por ejemplo, es el resultado de la acumulación de determinadas alteraciones genéticas en determinados tipos celulares que conducen a la adquisición de características de proliferación y diferenciación anormales. La manipulación genética de esas células podría reparar algunas de esas alteraciones o hacer que las células tumorales expresen determinados antígenos frente a los que el sistema inmune pudiese inducir una respuesta eficaz para la eliminación de las células cancerosas. 
2. Anticuerpos monoclonales: A mediados de los años 1970 G. Köhler y C. Milstein divisaron un método para la producción ilimitada de anticuerpos de una sola especificidad (6); es decir, que reconocen solo un determinado epítopo. El método consistía en la fusión de dos células distintas de ratón en cultivo para generar lo que se dio en llamar un hibridoma. Una de las células originales provenía de un tipo de tumor, denominado mieloma, que deriva de linfocitos B (encargados de la producción de anticuerpos), y que tiene la propiedad de crecer ilimitadamente en cultivo. La otra célula era simplemente un linfocito B obtenido del bazo de un ratón que había sido previamente inmunizado con un determinado antígeno. Entre las células del bazo de ese ratón debería haber una proporción de linfocitos B que produjesen anticuerpos dirigidos frente al antígeno que se empleó en la inmunización. Según la teoría clonal de Jerne, un linfocito es capaz de producir moléculas de anticuerpo de una sola especificidad.

El método de Köhler y Milstein consistió en fusionar células de mieloma de ratón con células de bazo de un ratón inmunizado (Figura 2). Así se generaron células híbridas (hibridomas) que mantenían la capacidad de las células de mieloma de crecer ilimitadamente en cultivo y la capacidad de los linfocitos del bazo de producir un determinado tipo de anticuerpos. Mediante el uso de «trucos» genéticos se podían seleccionar estos hibridomas y posteriormente identificar aquellos que eran productores del anticuerpo deseado. La posibilidad de crecer continuamente estos hibridomas en cultivo hacía de estas células una fuente inagotable de anticuerpos.

Mientras que los antisueros que se habían utilizado anteriormente al advenimiento de los hibridomas eran mezclas complejas de anticuerpos con especificidades distintas (deseadas y no deseadas), cada hibridoma producía un anticuerpo de una sola especificidad, denominado anticuerpo monoclonal.

La especificidad única de los anticuerpos monoclonales, junto con la posibilidad de disponer de una fuente inagotable de los mismos (los hibridomas), ha hecho que este tipo de anticuerpos hayan desbancado a los antisueros tradicionales en un gran número de aplicaciones. Además, mientras que la disponibilidad de un antígeno purificado era casi un requisito imprescindible para la inmunización de animales y la obtención de los antisueros, este requisito puede obviarse en el caso de los anticuerpos monoclonales. Aunque la inmunización se haga con una mezcla compleja de antígenos, la selección de un determinado hibridoma siempre conduce a la producción de un solo tipo de anticuerpo. 


\section{Biotecnología y medicamentos}

FigURA 2. Esquema del procedimiento empleado por Köhler y Milstein.

Para la obtención de hibridomas productores de anticuerpos monoclonales
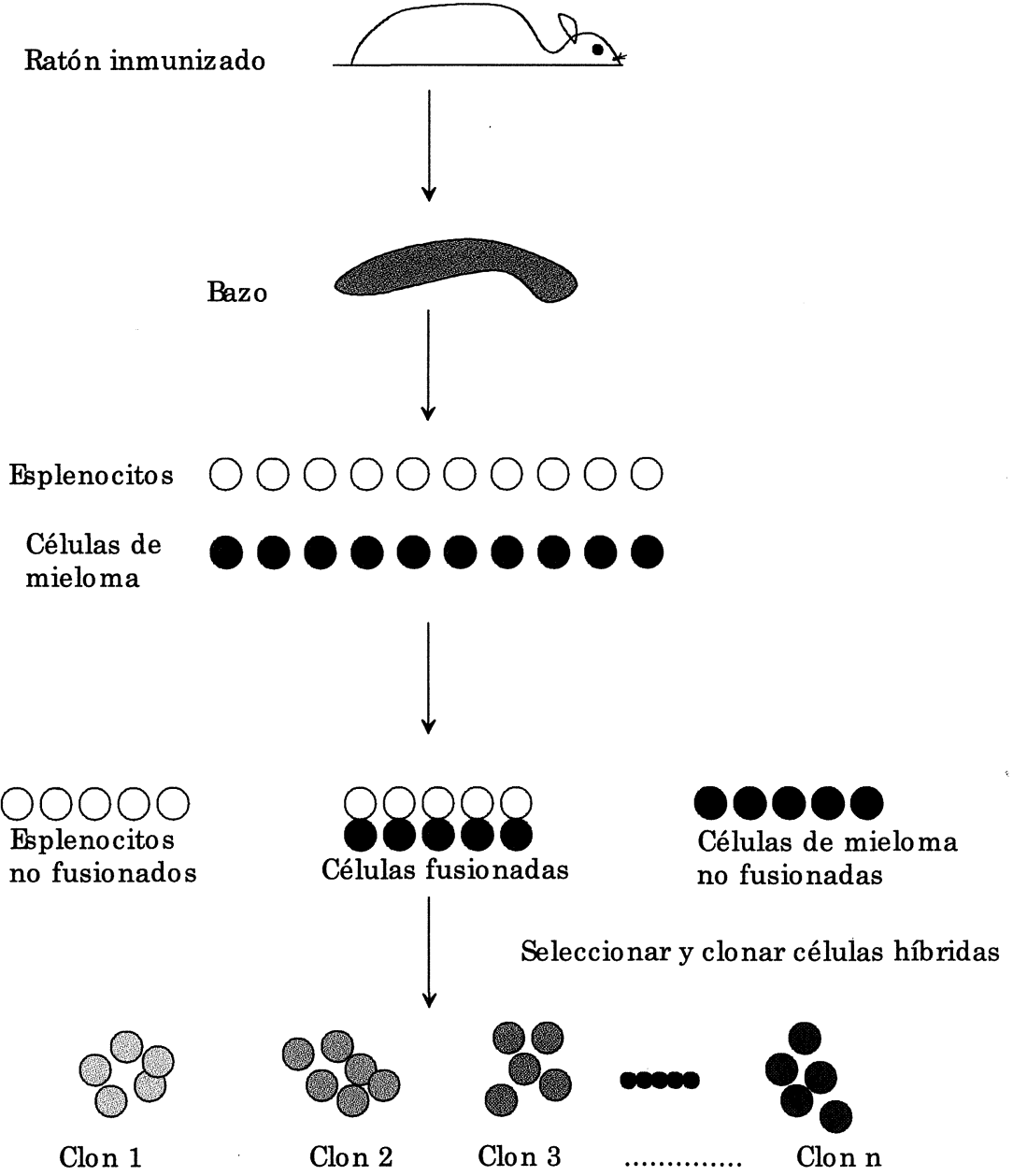

Se extrae el bazo de un ratón inmunizado previamente y se dispersan sus células. Estas se fusionan con células de un mieloma. Las células fusionadas se seleccionan y se derivan cultivos de cada célula fusionada (clones). Posteriormente se identifican los clones productores de los anticuerpos deseados probando el medio de cultivo donde se creció cada clon con el antígeno que se empleó en la inmunización del ratón.

Los anticuerpos monoclonales no solo han desbancado a los antisueros, sino que además han ampliado enormemente sus aplicaciones no solo en el diagnóstico clínico sino también, recientemente, en el uso terapéutico de los anticuerpos. 
2.1. Diagnóstico: La alta afinidad de los anticuerpos por sus antígenos los hacen herramientas idóneas para un gran número de pruebas diagnósticas. El advenimiento de los anticuerpos monoclonales junto con el desarrollo de métodos fáciles de estandarizar y de procesar un gran número de muestras han revolucionado las técnicas de inmunodiagnóstico tradicionales. Así, hoy en día es posible el «screening» de todas las donaciones sanguíneas para la presencia de virus infecciosos, como son el virus de la hepatitis B o el virus del SIDA, por citar solo unos ejemplos. Esto ha permitido aumentar considerablemente el grado de seguridad de las transfusiones de sangre o eliminar un buen número de riesgos en la producción de hemoderivados, tales como la albúmina o los factores de coagulación sanguínea.

Las propiedades de los anticuerpos monoclonales también ha ampliado las pruebas diagnósticas «in vivo». Por ejemplo, se puede inyectar un anticuerpo monoclonal que lleve incorporado una marca radiactiva con el fin de visualizar un tumor que exprese un antígeno reconocido por ese anticuerpo. El desarrollo de técnicas que permitan visualizar otro tipo de marcas, no radiactivas, contribuirá con toda seguridad a un aumento del número de pruebas diagnósticas que utilicen anticuerpos monoclonales.

2.2. Terapia: Las aplicaciones terapéuticas de los anticuerpos monoclonales han tardado bastante más tiempo en desarrollarse que las de diagnóstico. No obstante, en los últimos años han empezado a incorporarse los anticuerpos monoclonales al arsenal de productos medicinales para uso terapéutico en humanos (Tabla II).

El primer anticuerpo monoclonal que se aprobó en la Unión Europea para uso terapéutico fue el OKT3, un anticuerpo que reconoce un antígeno presente en los linfocitos $\mathrm{T}$ (responsables de la inmunidad celular) y que se utiliza para inducir una inmunosupresión en los receptores de transplantes renales y evitar así su rechazo. Aunque se preveía una inmediata aplicación de los anticuerpos monoclonales al tratamiento de las enfermedades infecciosas -sustituyendo y ampliando los usos de la sueroterapia tradicional-, en realidad estos anticuerpos han tenido una lenta implantación en este campo. Sin embargo, en los últimos 3-4 años se ha autorizado el uso profiláctico en niños de alto riesgo del primer anticuerpo monoclonal neutralizante (Synagis) dirigido frente a la glicoproteína $\mathrm{F}$ del virus respiratorio syncytial, primer agente causal de infecciones respiratorias graves en niños de corta de edad. Es muy probable que al Synagis le sigan en breve otros anticuerpos capaces de neutralizar la infección por virus, bacterias o parásitos causantes de enfermedades en humanos. Uno de los más buscados es, sin duda, un anticuerpo capaz de 


\section{Biotecnología y medicamentos}

neutralizar al virus del SIDA, existiendo en la actualidad algunos candidatos que se están empezando a utilizar en ensayos clínicos.

Es muy probable que el uso terapéutico de los anticuerpos monoclonales se potencie con la utilización de anticuerpos «humanizados» o de anticuerpos totalmente humanos. La técnica de Köhler y Milstein para la producción de anticuerpos monoclonales murinos (de ratón) no ha sido fácil de implementar para la producción de anticuerpos monoclonales humanos. Entre otras causas cabe mencionar la falta de células de mieloma humano con las propiedades adecuadas para la producción de hibridomas y la imposibilidad de inmunizar a humanos frente a cualquier antígeno, por razones éticas obvias. Por ello, la mayoría de los anticuerpos monoclonales que se han obtenido hasta el momento son de origen murino. Estos anticuerpos, sin embargo, pueden encontrar ciertas dificultades para su uso en humanos, por la posibilidad de que el sistema inmune del receptor dispare una respuesta inmune frente a una proteína foránea.

Los anticuerpos humanizados son el producto de la manipulación de los genes que codifican las cadenas pesada y ligera de un determinado anticuerpo murino. En estos genes se reemplaza el $95 \%$ de sus secuencias de nucleótidos por las regiones análogas de los genes correspondientes a anticuerpos humanos, manteniendo solamente el 5\% de los genes originales, lo que preserva su especificidad. Los genes manipulados se reintroducen en células de mieloma murino que ahora producen ilimitadamente el anticuerpo "humanizado».

Una mayor ventaja puede ser el uso de anticuerpos totalmente humanos obtenidos a partir de ratones «humanizados». Estos son ratones «transgénicos» en los que los genes que codifican para los anticuerpos endógenos se han eliminado en gran parte y se han reemplazado por la parte del genoma humano que contiene genes equivalentes. Estos ratones «humanizados» son capaces de responder frente a una inmunización montando una respuesta inmune en la que los anticuerpos que se producen tienen solamente secuencias de origen humano. La inmortalización de los linfocitos productores de estos anticuerpos, mediante la fusión con células de mieloma murino, da lugar a hibridomas productores de anticuerpos monoclonales humanos.

Otras aproximaciones para la producción de anticuerpos monoclonales humanos se basan en la ingeniería genética y no en la técnica de fusión celular utilizada originalmente por Köhler y Milstein para producir los primeros anticuerpos monoclonales. De la misma manera que se indicó anteriormente para el «clonaje» de los genes de diversas proteínas 
humanas, se pueden clonar los genes de las cadenas pesada y ligera de un determinado anticuerpo humano y reintroducirlos, por ejemplo, en cé lulas en cultivo para la producción ilimitada de ese anticuerpo. La puesta a punto de sistemas de selección y "screening» masivos permite identificar aquellas células productoras del anticuerpo deseado.

3. PCR: Aunque la técnica de amplificación en cadena de la polimerasa ("Polymerase Chain Reaction», PCR) no haya tenido una aplicación directa para la producción de productos medicinales de uso profiláctico o terapéutico, merece la pena mencionarla aquí por las enormes repercusiones que ha tenido en el campo de la Biotecnología. El principio básico de esta técnica se muestra en la Figura 3. El impacto de esta técnica en la ingeniería genética se debe a la posibilidad que la PCR ofrece de amplificar millones de veces un gen determinado en el tubo de ensayo, sin tener que clonarlo previamente. Esto ha facilitado el aislamiento de genes únicos de nuestro genoma cuya obtención habría resultado enormemente tediosa utilizando otras técnicas. Así mismo, la posibilidad de disponer de grandes cantidades de una muestra homogénea de un determinado gen facilita su clonaje y posterior caracterización de su producto génico. Por ello, la PCR se ha instaurado en muchos laboratorios como una etapa previa al proceso de clonaje de genes en plásmidos u otros vectores.

FIGURA 3. Esquema de la reacción en cadena de la polimerasa

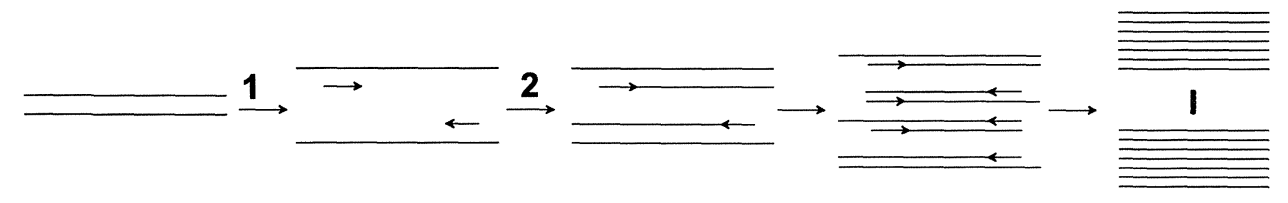

Una molécula de DNA se desnaturaliza (separan las cadenas) y se hibrida con dos oligonucleótidos, indicados por fechas cortas en sentido contrario (etapa 1), que sirven como iniciadores para la sintesis de nuevas cadenas por la acción de la DNA polimerasa (etapa 2). Las etapas 1 y 2 se repiten decenas de veces con lo que se obtiene una amplificación exponencial del número de móleculas de DNA con secuencias comprendidas entre los dos oligonucleótidos.

La técnica de PCR ha tenido además un impacto importante en el diagnóstico clínico. Así, por ejemplo, hoy en día se puede cuantificar el contenido de genomas del virus del SIDA en la sangre de enfermos portadores de este virus, sin tener que utilizar las tediosas técnicas tradi- 


\section{Biotecnología y medicamentos}

cionales de cuantificación del virus mediante inoculación de muestras de sangre en cultivos celulares. El número de genomas virales en la sangre de individuos portadores del virus del SIDA es un parámetro pronóstico del desarrollo de la enfermedad.

4. Genómica y proteómica: Estos dos términos han saltado a las páginas de las revistas científicas en los últimos 5-6 años y se han extendido rápidamente hasta ser los temas centrales de nuevas publicaciones periódicas.

La genómica se entiende como aquella parte de la Biotecnología que tiene que ver con el estudio del genoma de distintos organismos. Una vez conseguida la secuencia de nucleótidos completa del genoma de diversos microorganismos (bacterias y levaduras), de organismos inferiores (la mosca del vinagre) e incluso del genoma humano, se ha empezado a hablar de la "genómica funcional». Es decir, ya no se trata de averiguar cuantos genes tiene el genoma humano, ni el orden de los mismos en los distintos cromosomas; mas bien, se trata de entender como se regula la expresión de esos genes en las distintas células del organismo y como se coordinan unos genes con otros para que el organismo funcione.

Uno de los avances tecnológicos más importantes en el campo de la genómica ha sido el desarrollo de los denominados "arrays» o «chips» de DNA (Figura 4) (7). Utilizando robots de alta precisión se pueden construir actualmente «chips» en los que se han depositado en superficies de vidrio un gran número de microgotas que contengan distintas secuencias de DNA. Hoy en día se pueden disponer decenas de miles de secuencias distintas de DNA en superficies de un $\mathrm{cm}^{2}$. Estos arrays de DNA tienen un gran número de aplicaciones tanto en la investigación básica como aplicada.

Por ejemplo, esos arrays de DNA se pueden utilizar para identificar aquellos genes que se expresan (están activos) en un tipo celular y no en otro. Esto nos dará no solamente una información cuantitativa sobre la expresión diferencial de diversos genes en tipos celulares distintos sino además una información cualitativa de cómo diversas agrupaciones de genes es probable que actúen coordinadamente, por ejemplo, en procesos tales como la diferenciación celular. De la misma manera, se puede analizar la expresión de genes en un tumor frente al correspondiente tejido normal. Esto está permitiendo hacer una nueva clasificación de determinados tumores, basándose en analogías entre las alteraciones genéticas detectadas. Esta nueva clasificación, a su vez, pretende explorar las posibilidades de esta tecnología para mejorar el pronóstico de determinados tumores o para diseñar drogas o tratamientos terapéuticos más indivi- 
dualizados para cada tipo de tumor. Estas últimas aplicaciones entrarían a formar parte de lo que se ha dado en llamar farmacogenómica.

FIGURA 4. Ejemplo de utilización de microchips de DNA

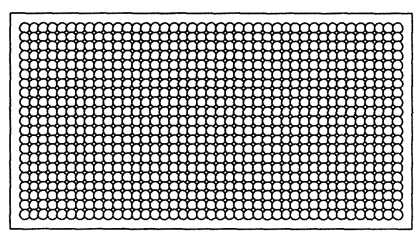

Hibridar con sonda de

$\stackrel{\text { Tejido normal } \longrightarrow}{\longrightarrow}$
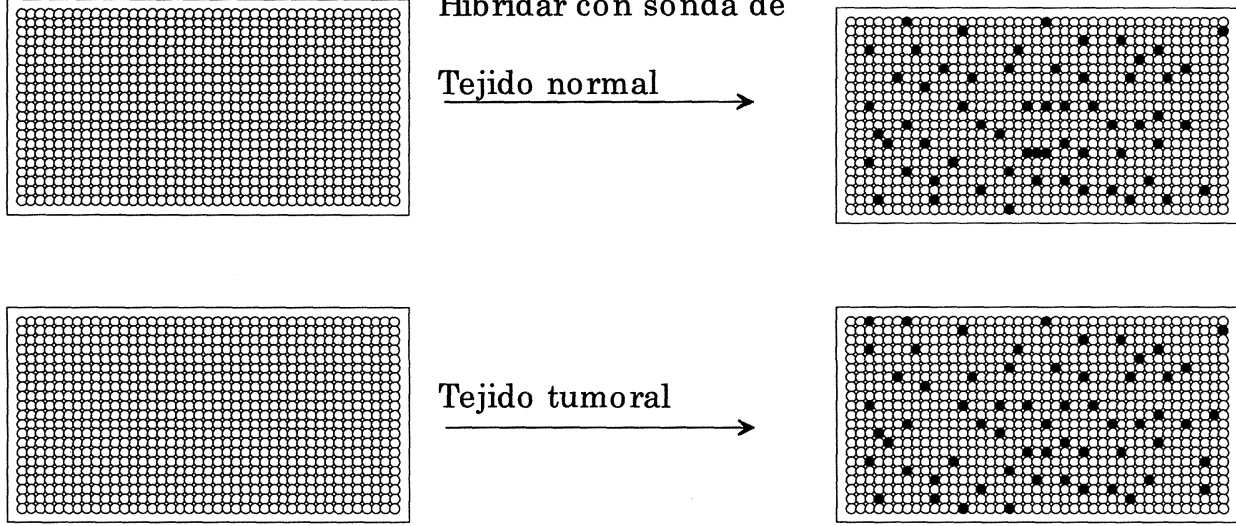

Tejido tumoral

Cada uno de los puntos del chip contiene un segmento de DNA correspondiente a un gen. En cada punto los genes representados son distintos. Dos chips idénticos se hibridan con sondas obtenidas a partir de RNA de células normales o tumorales. Las sondas llevan una marca que puede ser radiactiva, fluorescente, etc. Después de la hibridación (unión al DNA presente en los puntos) se visualiza la marca de la sonda, observándose que en el RNA de las células normales y tumorales hay representados genes indénticos, pero también hay otros que son exclusivos de cada tipo celular.

Mientras que la genómica se centra en el estudio del material genético, la proteómica se centra en el estudio de las proteínas codificadas por ese material genético. Hay razones que justifican el análisis directo de las proteínas que se expresan en un determinado tipo celular y no solamente de los genes que estén activos en esas células. Una de esas razones es que en la célula existen diversos niveles de control de la producción y actividad de una proteína, aparte de la transcripción del gen correspondiente. Así, hay proteínas que necesitan una serie de modificaciones postraduccionales para ser activas tales como la adición de azúcares, grupos fosfato, etc.

La proteómica se basa en el uso de técnicas de alta resolución para separar las proteínas presentes en un determinado tipo celular y de técnicas muy sensibles de análisis para identificar esas proteínas. Aunque hay otras alternativas, las técnicas de proteómica actuales tienen como base la separación electroforética bidimensional de las proteínas en un 
soporte semisólido y su identificación mediante espectrometría de masas, que permite tener una estimación precisa de la masa molecular de las proteínas o de fragmentos de las mismas.

Aunque la proteómica no ha tenido hasta ahora un desarrollo tan espectacular como el de la genómica, puede desplazar a esta en el futuro para los estudios de diferenciación celular o de clasificación en tumores que se mencionaron anteriormente.

5. Otras tecnologías: Lo dicho hasta ahora no abarca todas las posibilidades que ofrecen las Ciencias Biológicas modernas para mejorar la Salud Pública. Hay otros campos que tendrán también un papel importante para el desarrollo de nuevos tests de diagnóstico o de nuevos productos medicinales, así como para ampliar nuestros conocimientos de las bases fisiopatológicas de la enfermedad.

Las técnicas para la determinación de la estructura tridimensional de las proteínas seguramente tendrán un importante impacto en el diseño de nuevos fármacos en el futuro. Mientras que las técnicas de difracción de rayos $\mathrm{X}$ a partir de proteínas cristalizadas siguen siendo las más utilizadas para determinar la estructura de proteínas de tamaño medio o grande, las nuevas técnicas de resonancia magnética nuclear se van imponiendo para determinar la estructura de proteínas de pequeño tamaño. Estas últimas tienen la ventaja de que la proteína no tiene que cristalizarse previamente, paso limitante en muchos casos para la difracción de rayos $\mathrm{X}$.

El conocimiento de la estructura de una proteína puede ser la base para el diseño de drogas que puedan bloquear su función o potenciarla, utilizando programas de modelado molecular que se están desarrollando espectacularmente con las técnicas de bioinformática.

Otras tecnologías que tendrán un gran desarrollo en los próximos años serán las que se emplean para el estudio de interacciones entre distintas biomoléculas (8). Con estas técnicas se podrá hacer un mapa completo de las interacciones que tienen lugar entre las distintas proteínas de un determinado tipo de célula, o entre esas proteínas y otras biomolé culas. Además de aportar un conocimiento de gran valor para entender la fisiología celular, nos permitirá diseñar drogas que inhiban esas interacciones y, así, evitar posibles alteraciones patológicas.

En resumen, la Biotecnología nos ofrece hoy en día una serie de técnicas para la manipulación de organismos y producción de biomoléculas que están encontrando aplicaciones cada vez más importantes en la farmacología humana. Esta nueva etapa en el desarrollo de productos medicinales está en sus comienzos y es fácil aventurar que, en los próximos 
años, los nuevos medicamentos serán en gran medida de origen biotecnológico.

\section{Bibliografía:}

1. Cohen, S.N., Chang, A.C.Y., Boyer, H.W. AND Helling, R.B. (1973): Construction of biologically functional bacterial plasmids. Proc. Natl. Acad. Sci. USA. 70: 3240-3244.

2. JACKsON, D.A., Symons, R.H. AND BERG, P. (1972). Biochemical method for inserting new genetic information into DNA of Simina Virus 40: Circular SV40 DNA molecules contianing lambda phage genes and the galactose operon of Escherichia coli. Proc. Natl. Acad. Sci. USA. 69: 2904-2909.

3. Thomas, M., CAMERon, J.R. AND DAvies, R.W. (1974): Viable molecular hybrids of bacteriophage lambda and eukaryotic DNA. Proc. Natl. Acad. Sci. USA. 71: 4579-4583.

4. Gonzalo, R.M., Rodríguez, D., García-Sastre, A., Rodríguez, J.R., Palese, P. ANd EsTEBAN, M. (1999): Enhanced CD8+T response to HIV-1 env by combined immunization with influenza and vaccinia virus. Vaccine 17: 887-892.

5. Ulmer, J.B., Donnelly, J.J., Parker, S.E., Rhodes, G.H., Felgner, P.L., Dwarki, V.J., Gromkowski, S.H., Deck, R.R., DewitT, C.M., Friedman, A., Hawe, L.A., Leander, K.R., Martínez, D., Perry, H.C., Shiver, J.W., Montgomery, D.L. AND LiU, M.A. (1993): Heterologous protection against influenza by injection of DNA encoding a viral protein. Science 259:1745-1749.

6. KöhleR, G. AND Milstein, C. (1975): Continuous cultures of fused cells secreting antibody of predefined specificity. Nature 256: 495-497.

7. SCHUlZE, A. AND DownWARD, J. (2001): Navigating gene expression using microarraysa technology review. Natuce Cell Biol. 3: 190-195.

8. TuCKeR, C.L. AND Fields, S. (2001): A yeast sensor of ligand binding. Nature Biotec. 19: $1042-1046$.

\section{Glosario:}

ANTígeno: Sustancia que se emplea para la inmunización. Generalmente moléculas de proteína o microorganismos inactivados o atenuados.

ENZIMA DE RESTRICCIÓN: Enzimas que reconocen y cortan moléculas de DNA en secuencias específicas de nucleótidos.

EPÍTOPO: Región de un antígeno que es reconocida por un determinado anticuerpo.

Hibridoma: Célula resultante de la fusión de un linfocito productor de anticuerpos y de una célula derivada de un tumor maligno, denominado mieloma.

OligONUCLEÓTIDO: Segmento pequeño de DNA. Generalmente se obtiene por síntesis química.

PLÁSmIDO: Molécula de DNA circular presente frecuentemente en bacterias y que confiere resistencia a un determinado antibiótico a la bacteria portadora.

TRANSGÉniCO: Organismo en cuyo genoma se ha introducido un gen exógeno.

Vector: Molécula de DNA que se utiliza para insertar otro DNA foráneo. Generalmente es un plásmido o un genoma viral. 